\title{
The Impact of Online Consumer Reviews (OCR) on Online Consumers' Purchase Intention
}

\author{
Kalthoum DHAHAK (D) a Farid HUSEYNOV iD b \\ a Istanbul Aydin University, Graduate Education Institute, Istanbul, Turkey. kalthoumdhk@yahoo.com \\ b Gebze Technical University, Department of Management, Kocaeli, Turkey. fhuseynov@gtu.edu.tr
}

\begin{tabular}{|c|c|}
\hline ARTICLE INFO & ABSTRACT \\
\hline $\begin{array}{l}\text { Keywords: } \\
\text { Online Shop }\end{array}$ & $\begin{array}{l}\text { Purpose - The goal of this research is to examine the impact of Online Consumer Review (OCR) on } \\
\text { online customer purchasing intention in online shopping sector in Turkey. }\end{array}$ \\
\hline Online customer review & Design/methodology/approach - In this study, quantitative research techniques were utilized. \\
\hline Purchase intention & Primary data of the study was collected through a self-administered Likert type online survey. In \\
\hline Trust & total, 200 volunteer participants familiar with online shopping filled the study survey. The research \\
\hline TAM & $\begin{array}{l}\text { model of the study was analyzed with the help of confirmatory factor analysis (CFA) and structural } \\
\text { equational model (SEM) techniques. }\end{array}$ \\
\hline $\begin{array}{l}\text { Received } 7 \text { January } 2020 \\
\text { Revised } 24 \text { April } 2020 \\
\text { Accepted } 4 \text { May } 2020\end{array}$ & $\begin{array}{l}\text { Findings - According to the findings of this research, customer decision to shop online from e- } \\
\text { vendors and their trust in them are influenced by perceived effectiveness, perceived ease of use, } \\
\text { perceived control, perceived usefulness, and perceived usefulness from OCRs. }\end{array}$ \\
\hline $\begin{array}{l}\text { Article Classification: } \\
\text { Research Article }\end{array}$ & $\begin{array}{l}\text { Discussion - OCRs has recently been known and considered as a very important tool for both } \\
\text { businesses and customers to get information needed about any products and services through } \\
\text { different experiences of previous customers. This study investigated the role of OCRs in influencing } \\
\text { online customer purchasing intention. Trust was found to have a mediator role between OCR related } \\
\text { factors and online purchase intention. Finding of this research can be used by online business owners } \\
\text { to enhance the experience level of their customers. }\end{array}$ \\
\hline
\end{tabular}

\section{Introduction}

Online consumer reviews (OCRs) have become an important topic on various types of e-commerce platforms. A great deal of online business owners provides a functionality on their online platforms to enable their customers to leave comments about their products and services. Consumers who buy online lean strongly on other users' reviews to evaluate the quality of the product. Unlike traditional channels, where customers can see the products directly, online channels do not provide customers with the opportunity to look directly at the product. Instead, customers get product information in two ways: Information that sellers describe (images, sizes, etc.) and online reviews that other customers provide. Online consumer review plays an important role as an influencer factor, with the fast proliferation of the Internet, consumers share and publish their post-purchase experiences through online communications. The information search from personal sources has been the main subject of numerous studies of consumer behavior and it has been broadly reported that personal information sources apply an interpersonal influence on the consumer, especially when their arguments or characteristics can persuade the consumer (Bertrandias, 2006). Additionally, OCRs are considered to be very important in helping consumers' purchase decisions (Chevalier and Mayzlin, 2006, Kim and Hollingshead, 2015).

Nowadays online shopping becomes more and more popular among social media and e-commerce. More customer is purchasing online and sharing their opinions and comments in the online reviews providing much information and experience about products and services to other customers. The OCRs might be helpful to develop a highly effective marketing strategy for businesses so that customers can write reviews to help future customers get their products and many businesses have already started adopting the strategy of an online consumer review. However, with all the benefits that online consumer reviews offer, some companies are still not aware of how important and serious it is and how it can influence their customers' purchase decisions. 
The main objective of this research is to analyze the impacts of OCRs features (Perceived effectiveness, perceived usefulness, perceived enjoyment, perceived control and perceived ease of use) on customer purchase intention and trust as a mediator variable within the online shopping sector of Turkey. An examination by Nielsen in 2018 indicated that $4 \%$ of Turkish consumers shop online every day, while $46 \%$ request products and services online just a couple of times each month. A considerable lot of these consumers consult OCRs before purchasing their things since it is a significant impact factor. Individuals in this way find OCRs helpful for settling on better purchase decisions (Cheung et al., 2008; Park and Kim, 2008; Senecal and Nantel, 2004; Yayli and Bayram, 2012).

\section{Theoretical Background}

The online customer review is known to be one of electronic word of mouth (eWOM) types which is described as "peer-generated product evaluations" posted on company or third-party websites" (Mudambi and Schuff, 2010), which are referred to as any negative and positive comments about a service or a product written by some potential customers, which is accessible to a large number of person and establishments through the Internet (Hennig-Thurau et al. 2004). Online reviews are known to be on many websites as common features and they are becoming a necessary and important force in marketing (Cui et al., 2012). Information from other consumers, like online reviews, is viewed to be more convincing because it is reputedly written by other consumers rather than brands, and is therefore considered as being more credible and trustworthy (Willemsen et al., 2012). The role of online customer reviews according to a number of studies consist of playing two roles at the same time, one as a source of information and the other as a source of recommendation (Park et al., 2007; Park \& Kim, 2008; Park \& Lee, 2008). Park et al., (2007) stated that the OCRs as an informant are likely to be highly oriented toward customers whereas as a recommender, it comes in as a format containing various recommendation regardless of being negative or positive. According to Park and Lee (2008) that the two roles of OCRs may fully satisfy the needs of customers. However, Li, Hitt, Zhang (2011) claimed that they identified three reasons that could make OCRs not fully informative. To start with, reviews can't be absolutely perfect; mistakes consistently exist. Second, companies may pay reviewers to supply a constructive review, which reduce the usefulness of reviews. To finish with, because of the various inclinations that may occasionally be found among clients and reviewers, especially in the products' experience, reviews may not be totally enlightening. As stated by Schindler and Bickart (2012) to make a review helpful the number of positive statements should be moderate so that the review can be considered as valuable but at the same time it should not include too much positive statement because it may increase doubts about the review's incentives. They also established that three other points can be related to a helpful review; which are the descriptive statements number, the statement numbers, and the positive style usage. Moreover, one-sided reviews are likely to reduce helpfulness than two-sided or balanced reviews (Cheema \& Papatle, 2010; Sen, 2008). Adding to that, a shorter review is viewed to reduce utility than longer ones (Baek, Ahn, \& Choi, 2012; Mudambi \& Schuff, 2010; Pan \& Zhang, 2011; Sen, 2008).

The laboratory experiment of Li et al. (2013) shows that the perceived review helpfulness is influenced by the. source credibility, review contents, and the using of indirect terms and expression. According to research, people care about negative reviews more than positive ones despite their questionable credibility. However, negative reviews provide some unexpected benefits that can be just as useful as positive reviews to influence potential customers. One of those benefits is that it increases customer trust. Katie Hollar (2015) stated that $52 \%$ of buyers claimed that they are likely to trust a product more if it includes at least a few negative reviews. According to a study by Reevoo, $95 \%$ of customers doubt that reviews are controlled or fake on the off chance that they don't perceive any negative ones, and $65 \%$ trust reviews more when they find about both negative and positive ones. Jae Baer appointed that negative reviews are valuable and help and offer an opportunity to save a situation and relationship with the customers.

\section{Theoretical Model and Hypotheses Formulation}

The research model of this study (Figure 1) was developed based on the existing literature. There are five independent factors and two dependent factors in this model. Independent variables are perceived effectiveness, perceived enjoyment, perceived usefulness, perceived control, and perceived ease of use. On the other side, dependent variables are trust and purchase intention. The following subsections explain each factor within the scope of the existing literature. 


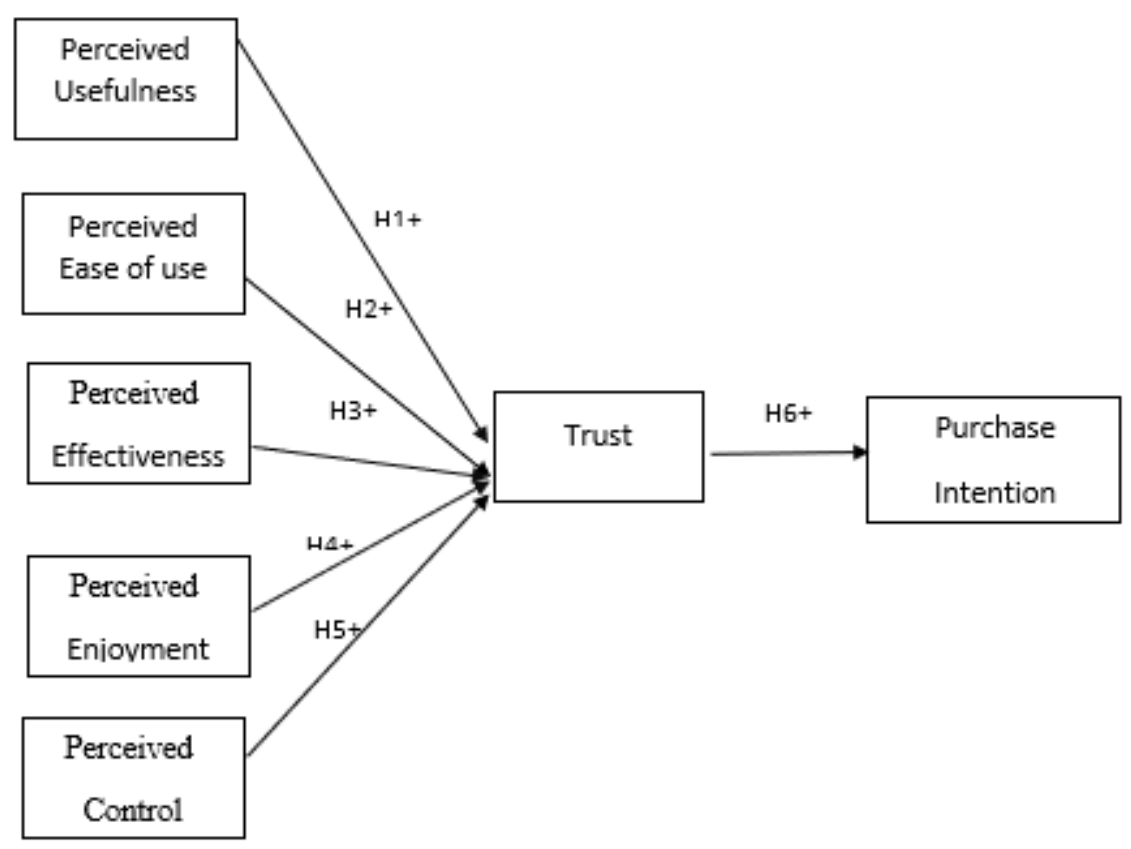

Figure 1. Conceptual Framework of the Study

\section{Perceived usefulness}

As stated by Davis (1989), Perceived usefulness (PU) takes a part of the independent constructs within the Technology Acceptance Model (TAM). He defined it as "the degree to which an individual believes that using a particular system would enhance his/her job performance" (Davis, 1989). Hassanein and Head's (2005) said that the original online trust model contains perceived usefulness construction that has the ability to meditate between online trust and social presence Despite some critiques existed in TAM based models within perceived usefulness contribution (Legris et al.,2003; Moon and Kim,2001), Diverse research have shown that perceived usefulness can greatly contribute to building trust in an online environment (Chen and Barnes, 2007, Gefen et al., 2003b, Horst et al., 2007). Koufaris \& Hampton-Sosa, (2004) deduced that each of perceived ease of use and usefulness is antecedents of e-commerce trust. Awad and Ragowsky (2008), found that perceived ease of use and perceived usefulness have an impact on trust in e-commerce. They also added that concerning OCRs, previous studies proposed that the systems of online reviews are in general used to enhance customers' trust in e-vendor. Additionally, Chen, $\mathrm{Wu}$, and Yoon (2004) argued that growth in sources of information can enhance client trust. As indicated by an eMarketer reference (2007), e-sellers who offer OCRs are more trusted by clients than other online sources. Customers usually provide voluntarily OCRs; where a significant trustworthiness level and credibility was created (Hu et al., 2010). Besides, Sen and Lerman (2007) demonstrated that regardless of the positive or negative information, customers tend to trust OCRs. Jarvenpaa \& Tractinsky \& Saarine (1999) show that according to the perceptiveness of the client when the level of their trust is high the usefulness of the e-seller site become more effective. In this consideration, Kumar \& Bennbasat (2006) proved that the availability of the OCRs devices rises the perceived usefulness of an e-vendor. Others found that the influence of the eWOM information had a great impact on the trust of customers (Xiaorong, Bin, Qinghong, Liuli, and Yu, 2011). The evaluation system is regarded to be beneficial and valuable part of a website and affect consumers' motive; thus, review usefulness can as well have an impact on the trust of the customer Consequently, we suggested the first hypothesis as:

Hypothesis 1: Perceived Usefulness of OCRs positively affects customer trust in e-vendors

\section{Perceived Ease of use}

Perceived ease of use was defined by Davis $(1989$, p. 320) as "the degree to which a person would be free of effort by believing in the use of a particular system". As stated by TAM, perceived ease of use, perceived usefulness, intention, and attitude were supposed to be the main factors influencing acceptance attitude (Agag \& El-Masry, 2016 Akman \& Mishra, 2015; Hsu \& Lin, 2008; Lai, Hsu, \& Chung, 2010; Lim, Lim, \& Heinrichs, 2008). Davis, Bagozzi, and Warshaw (1989) have claimed that improving ease-of-use can be essential as well, 
contributing to improved performance. Cho, Kwon, Lee (2007), Awad and Ragowsky (2008) claimed that in other subsequent studies the extended TAM explained the relationship between perceived ease of use and trust. Although some studies of the TAM suggested that, the perceived ease of use affected trust (Gefen et al., 2003). In addition, Awad and Ragowsky (2008) found that there is an impact on e-commerce trust from both technological attributes of perceived ease of use and perceived usefulness. Online shopping physical interaction absence demands the e-vendor to supply the information needed to improve customer trust (Ling, Daud, Piew, Keoy and Hassan, 2011). Lan \& Chen (2014) added that when the information on the website is clear, useful and easy-to-understand, it can reduce confusion due to unsymmetrical information and rise trust within online vendors. Another state that was said about perceived ease of use by Gefen et al. (2003) is that with the insight that an e-seller is using the purchaser-vendor relationship, the perceived ease of use can boost customer trust, thus indicate a relationship assurance. Like it was mentioned earlier in the perceived usefulness part, customers trust online vendors who supply OCRs more than trusting other online sources (eMarketer,2007). It is suggested that the perceived ease of use of OCRs, defined by their comprehensibility and clarity, has an impact on customer trust in the e-vendor (Gefen et al., 2003; Koufaris \& Hampton-Sosa, 2004). Therefore, we proposed the second hypothesis as:

Hypothesis 2: Perceived Ease of use of OCRs positively affects customer trust in e-vendors.

\section{Perceived Effectiveness}

Xinping, Ziqi (2017) in their study said that perceived effectiveness refers to consumers' evaluation of usability, social benefits and added value provided by an online intermediary. And it was believed that perceived effectiveness acts as a direct factor that enhances consumers' trust in institution-based intermediaries (Bolton and Lemon, 1999, Cronin et al., 2000). Since there are not many studies that identify the relationship between perceived effectiveness and trust, this study tries to find a positive relationship between these two factors basing on what was mentioned above. Therefore, the third hypothesis is proposed as below:

Hypothesis 3: Perceived Effectiveness of OCRs positively affects customer trust in e-vendors.

\section{Perceived Enjoyment}

Enjoyment is another significant driver for the use and adoption of new innovations (Davis et al., 1992, Lee et al., 2005, Venkatesh, 2000). Perceived enjoyment is perceived to be enjoyable in itself right by using activity as a specific system, apart from any consequence on performances resulting from the use of the system (Venkatesh, 2000, p. 351). This has given rise to the idea that enjoyment is a fundamental driver (Lee et al. 2005). The information systems' precedent investigations noted that to explain the use and adoption of information technology (IT) systems, they have adopted enjoyment as intrinsic motivation. On this subject, Davis et al. (1992) included perceived enjoyment among the major and principal factors of acceptance by extending the original TAM. Other researchers have reported that according to Davis et al. (1992), that perceived enjoyment and behavioral intent are connected and that this connection defines the key form of online shopping. On the other hand, HA and Stoel (2009) imply that the probability for customers to make online shopping is highly impacted by their enjoyment and satisfaction toward the shopping procedure. In addition, $\mathrm{Li}$, Chua, and $\mathrm{Lu}(2005)$ find that perceived enjoyment directly affects the intention of using instant messaging. Besides Koufaris (2002) reports that perceived enjoyment influence of the intention of online customers to come back to the online store is very important. Leaning on OCRs, perceived enjoyment is considered as a measure for which a client considers OCRs to be fun and entertaining. Enjoyment importance was highlighted by the researchers in the context of eWOM and OCRs. Enjoyment is also noted according to a study done by Schindler and Bickart (2005) as one of the five top reasons that drive people to look for online messages. Also, Cheung, Lee (2012) and Okazaki (2009) reveals that enjoyment is a significant motivator of engaging in eWOM. A quantitative and qualitative approach was employed by Phelps, Lewis, Mobilio, Perry, and Raman (2004), revealing that for forwarding an emails enjoyment is an essential driver. The current research tries to show the influence of perceived enjoyment of the OCRs on the trust of the customer using online shopping which leads to customer intention to purchase by considering the importance that perceived enjoyment has on online reviews and on the experience of online shopping. Moreover, the fourth hypothesis hypothesized as follows: 


\section{K. Dhahak - F. Huseynov 12/2 (2020) 990-1005}

Hypothesis 4: Perceived Enjoyment of OCRs positively affects customer trust in e-vendors.

\section{Perceived Control}

Hui, Bateson (1991) and koufaris (2002) define the perceived control as the degree of control that individuals practice on their actions and midst. Perceived Control is a belief and an assumption that the individual is able to make a difference in the events that surround their lives by influencing it. This belief helps a person to deal with the stress in their lives and take control of it. In the current research, perceived control will be referring to the control quantity that OCRs provide to a customer feels while going through the online shopping process. In the case of online shopping, perceived control is considerate to be a consequence of not only interaction with the product itself but also of the interaction behavior with the website and its features (Koufaris, 2002). According to Jarvenpaa and Todd (1996), Online shopping demands more control by customers, unlike physical shopping due to the amount of information that it provides and that leads to higher efficiency and less effort. Customer's sense of control increases when not having to go through a salesperson but rather obtaining and finding of buying information from a website directly (Wolfinbarger\& Gilly, 2001). The level of control is taken from by the experience of online shopping that is divided in two actions one for the raises customer's efficiency by lack of commitment and the other is by decreasing the required efforts for making a purchase (Wolfinbarger and Gilly, 2001).Wolfinbarger and Gilly (2001) reported that the level of perceived control is increased by obtaining and finding the information needed on websites and applying a system that enables the personalization of the information. However, Wolfinbarger and Gilly (2001), described the difficulty of spotting and finding such information; therefore, on the side of OCRs, it is easy to found and provide reliable and credible information based on previous customer's evaluation and experiences, which might be helpful in this regard. The fifth hypothesis is developed as follows:

Hypothesis 5: Perceived Control of OCRs positively affects customer trust in e-vendors.

\section{Trust}

Trust is usually described as a belief (Hampton-Sosa and Koufaris, 2005). It has been extensively studied over the years and has been viewed through diverse lenses and filters: economics, psychology, and sociology (Kim \& Park 2013). Trust is the willingness of a party (customer) depending on the actions of the other party (seller) where such action makes him (customer) vulnerable of the other party (seller) expecting him to perform an important action to the trust (Mayer et al .1995). Trust in online shopping is becoming a very important problem due to the trading relationships which are based on the impersonal nature of the internet infrastructure. Especially, consumers are confronted with the challenge of buying a product or service, which they cannot actually see or touch, from an unfamiliar seller. In the internet world, the major concerns are privacy and security. Hoffman, Novak, \& Peralta, (1999) stated that If there is no trust between customers and e-vendors than the e-vendor will never get customers' credit cards or personal information. Here, trust plays an essential role in e-vendor websites by influencing the actions of the customers (Hampton-Sosa \& Koufaris, 2005). It has also an important role in helping consumers defeat their perceptions risk and insecurities (McKnight, Choudhury, \& Kacmar, 2002). Especially when failing to supply a particular trustworthiness level, it may stop customers from engaging in online shopping. Also, knowing that customers are frequently careful and uneasy or even be anxious about e-vendor opportunistic behavior (Hoffman et al., 1999). Therefore, over time the online trust is slowly developed and formed as consumer earns experience through many and repeated transactions (Cheskin-Research, 1999). As soon as trust is made in an e-vendor there will be a positive and strong understanding toward online shopping by these customers, and it will arise a purchase intention as a result (Gefen et al., 2003). At the point, where consumers accept that the e-vendors are reliable, they are probably going to choose a vendor's website to make an online buying (Hampton-sosa and koufaris, 2005). In the current study, trust is described as the consumer's belief that the online vendor is not an opportunist and that online shopping security is enough to supply risk-free transactions. Considering the points that were mentioned above, the sixth hypothesis could be proposed as:

Hypothesis 6: Trust in e-vendors who provide OCRs positively affects customers' intentions to shop online. 


\section{Research Methodology}

\section{Instrument development}

The online questionnaire used in this study is composed of a 5-point Likert scale ranging from strongly disagree to strongly agree and adapted from previous studies. First, five items were developed for the Measurements of perceived usefulness, three of them were based on Gefen et al. (2003) and Koufaris (2002) and two of them were modified from Chung, Park, Wang, Fulk, \& McLaughlin (2010). Second, this study employed five items to manifest the perceived ease of use, three of them were also based on Gefen et al. (2003) and Koufaris (2002) and two others from Gefen et al. Third, five items were modified to measure perceived effectiveness from Cronin et al. (2000) and Sweeney and Soutar (2001). Fourth, perceived enjoyment was identified by five items three of them adopted from Van Dolen et al. (2007) and two of them from Kim et al. (2005). Moreover, the perceived control was assessed by adopting five items, three of them from Van Dolen et al. (2007) and the two others from Rose et al. (2012). The measurement from the trust was measured by 4 items, two of them changed to a positive form adopted from Lee and Turban (2001), and one item from Gefen et al. (2003), and one other item adopted from Palvia, (2009). Lastly, purchasing intention includes five items, three adopted from Gefen et al. (2003) and Hsu et al. (2013), one modified item from Palvia, (2009), and the last item also modified from Schlosser et al. (2006). The wording of the scale items was adapted according to the scope of the study.

\section{Data collection and sample size}

The data for this research was collected through self-administered online survey. The study questionnaire were made available to online participants in English language. For the collection of data, a method of convenience sampling was used in this research which is known to be a non-probability sampling technique. According to Smith and Albaum, (2005), this method is based on the researcher's judgments and does not involve any probabilities techniques. Pallant (2013) recommended using the following formula proposed by Tabachnick and Fidell (2007), for the multiple regression techniques which require a large sample size for generalization purposes: $\mathrm{N}>50+8 \mathrm{~m}$ Where: $\mathrm{N}=$ sample size $\mathrm{m}=$ the number of independent variables. Based on this formula required sample size for current research is $\mathrm{N}>82$ (number of independent variables equals four). On the other hand, as stated by Hoelter's index, the SEM method should exceed 200 for a sufficient size because it represents the data inadequate way (Byrne, 2010). Therefore, the present study attempted to receive at least 200 responses to meet both of the above-mentioned requirements.

\section{Statistical techniques}

The statistical techniques that were applied to current research are the Confirmatory Factor Analysis (CFA) and Structural Equational Model (SEM). According to Byrne (2010), thanks to the help of CFA the relationship between factors and their observed variable can be measured. At the same time, CFA is able to evaluate the validity of the measures while SEM allows theories to be tested quantitatively and it depends on the error factor. The main difference between CFA and SEM is the fact that CFA focuses on the relationship between the latent and observed variables, while SEM covers the structural path between the focusing (latent) variables. According to Harrington (2009), CFA can stand out as a unique analysis and considerate to be a part of SEM. IBM SPSS version 25 and IBM SPSS AMOS version 21 statistical software were used to analyze this research.

\section{Data Analysis}

The sample for the current study consisted of 200 complete responses. $40.5 \%$ of the respondents were male and $59.5 \%$ of the respondents were female. The age of survey participants varied between 18 and 41 years. $61.5 \%$ of the participant were single and $38.5 \%$ were married. $29 \%$ of the respondents earn $2500-3500 \mathrm{TL}$ per month then $24 \%$ earn between $3500-4500 \mathrm{TL}, 22.5 \%$ for other and $15 \%$ for $4500-5000 \mathrm{TL}$ and $9 \%$ for $5000 \mathrm{TL}$ or more. The majority of the responses have chosen "sometimes" as a response to the question of "how often do they shop online". which is rated as $40.5 \%$, then $21 \%$ for "often", $19.5 \% "$ rarely", and $13.5 \%$ have chosen "always". A considerable part of the survey participants (89.5\%) has done online shopping. 
K. Dhahak - F. Huseynov 12/2 (2020) 990-1005

Table 1. Demographic Profile of Respondents

\begin{tabular}{|l|l|l|l|}
\hline Demographics profile & & Frequencies & Percentage (\%) \\
\hline \multirow{4}{*}{ Gender } & Male & 81 & 40.5 \\
\cline { 2 - 4 } & Female & 119 & 59.5 \\
\hline \multirow{5}{*}{ Age } & 18 to 24 & 59 & 29.5 \\
\cline { 2 - 4 } & 25 to 30 & 82 & 41 \\
\cline { 2 - 4 } & 31 to 40 & 38 & 19 \\
\cline { 2 - 4 } & 41 to older & 21 & 10.5 \\
\hline \multirow{5}{*}{ Status } & Single & 123 & 61.5 \\
\cline { 2 - 4 } & Married & 77 & 38.5 \\
\cline { 2 - 4 } & TL2500 to TL3500 & 58 & 29 \\
\cline { 2 - 4 } & TL3500 to TL4500 & 29 & 24.5 \\
\cline { 2 - 4 } & TL4500 to TL5500 & 30 & 15 \\
\cline { 2 - 4 } & TL5500 or more & 18 & 9 \\
\cline { 2 - 4 } & Other & 45 & 22.5 \\
\hline \multirow{5}{*}{ Do you shop online } & Yes & 179 & 89.5 \\
\cline { 2 - 4 } & No & 21 & 10.5 \\
\hline Shopping rate & Never & 10 & 5.5 \\
\cline { 2 - 4 } & Rarely & 39 & 19.5 \\
\cline { 2 - 4 } & Sometimes & 81 & 21 \\
\cline { 2 - 4 } & Often & 42 & 13.5 \\
\cline { 2 - 4 } & Always & 27 & \\
\hline
\end{tabular}

Note: Percentages may not sum up to $100 \%$ due to missing data

\section{Validity and Reliability assessment}

To conduct a CFA, it is important to ensure reliability, convergent and discriminant validity. Table 2 shows the results of validity and reliability assessment conducted for this research. It was obtained based on Correlations and Standardized Regression Weights tables pulled back with the assistance of Amos software. Convergent validity has been established and proven by an AVE greater than 0.5 . Reliability has also been established and certified by a CR greater than 0.7 . Generally, discriminatory validity has been also discovered and it is evident from the fact that MSV being less AVE, except for Complaint Handling $(\mathrm{CH})$ where there was slight volatility (since MSV and AVE difference for this factor were insignificant, this imbalance was not taken into consideration).

Table 2. Validity and Reliability Assessment

\begin{tabular}{|l|l|l|l|l|l|l|l|l|l|l|l|}
\hline & CR & AVE & MSV & MaxR(H) & PI & PE & PC & TR & PEF & PU & PEOU \\
\hline PI & 0.853 & 0.594 & 0.671 & 0.872 & $\mathbf{0 . 7 7 1}$ & & & & & & \\
\hline PE & 0.809 & 0.586 & 0.508 & 0.815 & 0.713 & $\mathbf{0 . 7 6 5}$ & & & & & \\
\hline PC & 0.825 & 0.541 & 0.263 & 0.830 & 0.379 & 0.361 & $\mathbf{0 . 7 3 6}$ & & & & \\
\hline TR & 0.853 & 0.596 & 0.671 & 0.874 & 0.819 & 0.707 & 0.404 & $\mathbf{0 . 7 7 2}$ & & & \\
\hline PEF & 0.819 & 0.549 & 0.086 & 0.891 & 0.294 & 0.179 & 0.245 & 0.276 & $\mathbf{0 . 7 4 1}$ & & \\
\hline PU & 0.867 & 0.765 & 0.563 & 0.871 & 0.624 & 0.555 & 0.513 & 0.613 & 0.119 & $\mathbf{0 . 8 7 5}$ & \\
\hline PEOU & 0.749 & 0.501 & 0.563 & 0.762 & 0.530 & 0.528 & 0.464 & 0.628 & 0.128 & 0.750 & $\mathbf{0 . 7 0 8}$ \\
\hline
\end{tabular}

The composite reliability (CR) values of all variables, Perceived Usefulness (PU), Perceived Ease of Use (PEOU), Perceived Effectiveness (PEF), Perceived Enjoyment (PE), Perceived Control (PC), Trust (TR) and Purchase Intention (PI) are $0.867,0.749,0.819,0.809,0.825,0.853$ and 0.853 respectively. This means that CR of all these variables is greater than the threshold value of 0.7 , hence their $C R$ is acceptable. The Average Variance Extracted (AVE) values of all variables, PU, PEOU, PEF, PE, PC, TR and PI are 0.765, 0.501, 0.549, 0.586, 0.541, 0.596 and 0.594 respectively. AVE of all these variables is acceptable as the values are greater than the threshold value of 0.5. For Discriminant Validity, the Maximum Shared Variance (MSV) values of variables, PU, PEF, 


\section{K. Dhahak - F. Huseynov 12/2 (2020) 990-1005}

PE, and PC are $0.563,0.086,0.508$ and 0.263 respectively. This indicates that values are less than the threshold value of 0.5 (AVE) which means they are acceptable. On the other hand, the MSV value of PEOU, TR, and PI are $0.563,0.671$ and 0.671 respectively which indicates that these values are slightly higher than the threshold value of AVE and considered not to be a major problem.

\section{CFA}

While conducting CFA (Figure2) analysis there were 300 distinct sample moments identified which refers to the number of elements available in sample covariance matrix. 70 parameters were estimated which is leaving 230 degrees of freedom. With Chi-square value of 375,323 the probability level equivalents to 0.000 . Having $\chi 2 / \mathrm{df}=1.632 ; \mathrm{RMSEA}=0.056 ;$ PCLOSE $=0.154 ;$ SRMR $=0.047 ;$ GFI $=0.868 ;$ AGFI $=0.827 ;$ CFI $=0.941$ demonstrates good fit according to collected data within this study (Table 3).

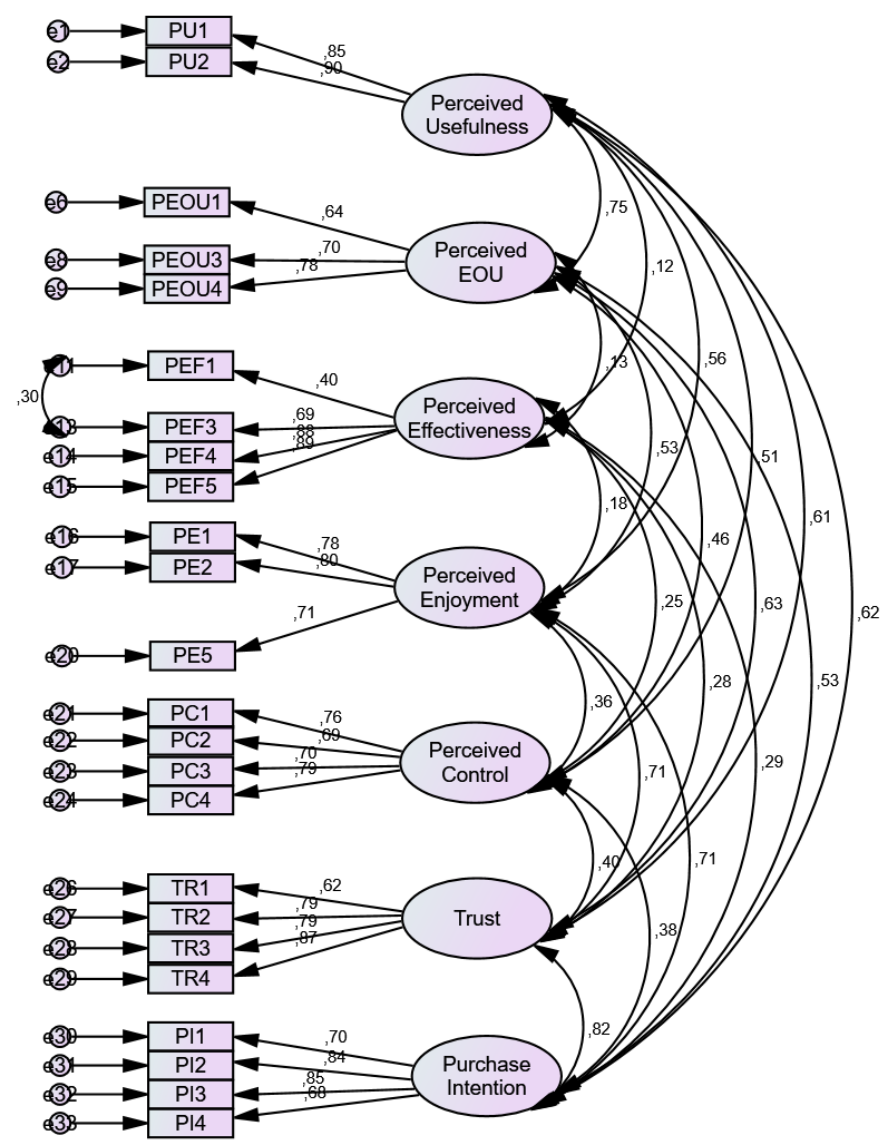

Figure 2. Confirmatory Factor Analysis

Table 3. Model Fit Analysis for CFA

\begin{tabular}{|c|c|}
\hline Measure & Model Result \\
\hline Chi-square (CMIN) & 375.323 \\
\hline CMIN/DF & 1.632 \\
\hline P-value & 0.000 \\
\hline CFI & 0.941 \\
\hline GFI & 0.868 \\
\hline AGFI & 0.827 \\
\hline SRMR & $0 . .047$ \\
\hline RMSEA & 0.056 \\
\hline PCLOSE & 0.154 \\
\hline
\end{tabular}

In order to examine hypotheses global (model fit and R-squared) and local (p-value) tests been conducted through Structural Equation Modeling (Figure 3). Model fit statistical results conducted for the structural equation model had the following results: Table 4 . The obtained results refer to goodness-of-fit. 
K. Dhahak - F. Huseynov 12/2 (2020) 990-1005

Table 4. Model Fit Statistical for SEM

\begin{tabular}{|c|c|}
\hline Measure & Model Result \\
\hline CMIN & 389.555 \\
\hline CMIN/DF & 1.658 \\
\hline P-value & 0.000 \\
\hline CFI & 0.937 \\
\hline GFI & 0.865 \\
\hline AGFI & 0.828 \\
\hline SRMR & 0.051 \\
\hline RMSEA & 0.057 \\
\hline PCLOSE & 0.112 \\
\hline
\end{tabular}

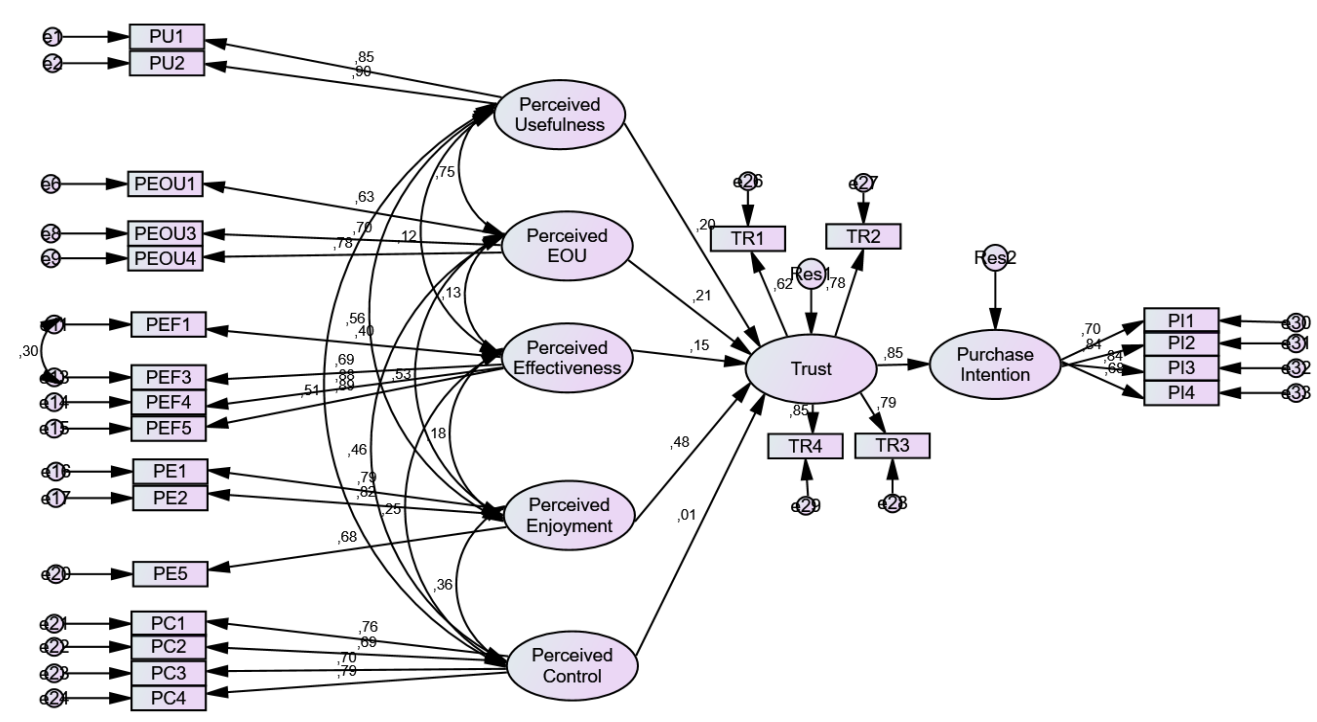

Figure 3. Structural Equation Model

Byrne (2010) defined R-squared and also known by the name of Squared Multiple Correlations (SMC) as an indicator of the level of variance (percentage) that predictors of the factors in question reflect. Having a minimum value of 0.158 and a maximum of 0.803 in SMC analysis it can be concluded that in general predictors explain respective variables relatively well.

Results of the hypotheses testing are summarized below.

- Perceived Usefulness is positively related to Trust thus Perceived Usefulness (PU) positively affects customers 'trust in e-vendor (H1: $ß=0.127$, S.E. $=0.073$, p-value $=0.084$ )

H1: Perceived Usefulness of OCRs positively affects customers' trust in e-vendors = Supported

- Perceived Ease of Use is positively related to Trust thus Perceived Ease of Use (PEOU) positively affects customers 'trust in e-vendor $(\mathrm{H} 2$ : $ß=0.180$, S.E. $=0.099$, p-value $=0.070)$

H2: Perceived Ease of Use of OCRs positively affects customers' trust in e-vendors = Supported

- Perceived Effectiveness is positively related to Trust thus Perceived Effectiveness positively affects customers' trust in e-vendor. (H3: $ß=0.226$, S.E. $=0.095$ and $p$-value $=0.018$ )

H3: Perceived Effectiveness of OCRs positively affects customers' trust in e-vendors = Supported

- Perceived Enjoyment is positively related to Trust thus Perceived Enjoyment positively affects customers' trust in e-vendor. (H4: $\$=0.381$, S.E. $=0.073$ and $p<0.001$ )

H4: Perceived Enjoyment of OCRs positively affects customers' trust in e-vendors = Supported 
- Perceived Control is not related to Trust thus Perceived Control (PC) does not affect customer trust in e-vendor. $(\mathrm{H} 5: \AA=0.007$, S.E. $=0.061$ and $\mathrm{p}$-value $=0.910$ )

H5: Perceived Control of OCRs positively affects customers' trust in e-vendors = Not Supported

- Trust is positively related to Purchase Intention thus Trust positively affects Purchase Intention (PI). $(\mathrm{H} 6: \AA=0.950$, S.E. $=0.126$ and $\mathrm{p}<0.001)$

H6: Trust in e-vendors who provide OCRs positively affects customers' intentions to shop online = Supported.

The summary of the hypotheses testing is provided in Table 4.

Table 4. Hypotheses Testing Results

\begin{tabular}{|c|c|c|}
\hline Hypotheses & Relationships & Status \\
\hline H1 & TR $\leftarrow$ PU & Supported \\
\hline H2 & TR $\leftarrow$ PEOU & Supported \\
\hline H3 & TR $\leftarrow$ PEF & Supported \\
\hline H4 & TR $\leftarrow$ PE & Supported \\
\hline H5 & TR $\leftarrow$ PC & Not Supported \\
\hline H6 & PI $\leftarrow$ TR & Supported \\
\hline
\end{tabular}

\section{Discussion and Conclusion}

This research aimed to understand the impact of online customer reviews on customer trust and purchasing intention particularly the online shoppers living in Turkey. OCRs is recently has been known and considered as a very important tool for both businesses and customers to get the information needed about any products and services through different experiences of previous customers. Moreover, it is regarded, that the results of this study will be important and invaluable for both businesses and research communities. By supporting business communities, it will supply a more understanding of consumers and how their choices and decisions are influenced by OCRs. It will also help businesses obtain useful acumen and feedback, which can lead to increase customer trust and will be providing them a valued tool to observe consumer purchase intention. This online information is probably considered as a major source that significantly influences customer buying intention. Depending on the reviewed theoretical background, it is very believable that OCRs will yet get more attentiveness in the coming years. Many resolutions of OCRs on this regard was revealed based on conducted literature review within this scope. This study also investigated the influence of the factors of OCRs on customer purchase intention and among these factors Trust is considered as a mediator variable. This investigation expands the TAM through the consideration of both perceived control from the Planned Behavior Theory and perceived effectiveness and applies the TAM examination in the context of the OCRs.

Primary data has been obtained for analysis of research questions and hypotheses testing purposes. In total there were 200 volunteer participants of the survey. The impacts of OCRs features were analyzed through CFA and SEM analysis. Within the scope of CFA, the model fit of the hypothesized model has been tested. $\chi 2 / d f$, RMSEA, SRMR, CFI, PCLOSE, GFI and AGFI. The results revealed a well fit model. SEM analysis covered hypotheses testing that included both global and local tests. The assessment of model fit showed a good fit and based on a squared $\mathrm{R}$ analysis it was concluded that the predictors explain the respective variable relatively well. After the global test, the local test was performed in terms of analyzing the p-value. According to the summary of hypotheses testing, five of the proposed hypotheses were statistically and significantly supported and one was unsupported.

The perceived usefulness has a strong direct impact on customers' buying intentions. According to precedent studies consisting of David (1989), Gefen et al. (2003), Limayem al. (2000), and Pavlou (2003) mentioned that perceived usefulness highly affects customer intention to do shopping online. The current study, therefore, confirm their work through results finding that support these studies by finding a positive relationship between perceived usefulness and trust with $p$-value $(p<0.5)$. The finding also shows that the second factor perceived ease of use which is considerate to be one of important antecedents of trust in the online context 
with perceived usefulness has a positive relationship with trust with a $p$-value $(p<0.5)$. Perceived enjoyment extract from OCRs also have a strong influence on customers' intention to shop online. This finding shows a positive relationship between perceived enjoyment a trust with $p$-value $(p<0.5)$. Perceived effectiveness is the fourth factor of OCRs and significantly affects customers' intention to shop online. The result reveals a positive relationship between perceived effectiveness and trust with $p$-value $(p<0.5)$. The perceived control of OCRs unfortunately unlike other factors was not supported, the finding was strongly negative with p-value $(\mathrm{p}=0.910)$. Finally, this study shows that trust is a precedent key for a customer's intention to shop online. According to the result of finding trust remarkably influences customers' intention to shop online with p-value $(\mathrm{p}<0.5)$. This research indicates that trust in e-vendors that provide OCRs positively affects customers' intentions to shop online and that the customers are perceived to perform more an online purchase when the e-vendor is seemed to be trustworthy.

\section{Implications}

By defining commonly discussed OCR features, current study focused on five of them: perceived effectiveness, perceived ease of use, perceived control, perceived usefulness and perceived enjoyment. This study found that all five mentioned features have either direct or indirect impact (through mediator variable trust) on customer intention to do shopping online. OCRs seem to supply a helpful way for e-vendors to increase sale. Consequently, customers may be encouraged to publish or to share reviews by those e-vendors and motivate them to be more active and participate in eWOM. Customer's decisions and intentions might be influenced by e-vendors through the use of OCRs. Also, trust within e-vendor may be established through supplying OCRs. The result of this study presents that OCRs assume a significant role, influencing customers' trust and intention, recommending that e-vendors enable consumers to share reviews on their websites. Another important finding is the fact that OCRs features like Perceived usefulness, Perceived effectiveness, Perceived enjoyment and perceived ease of use have a positive impact on Trust. This concludes that the results uncover that online shoppers, in general, attend to trust e-vendors who supply OCRs, which thusly impact customers' decision to purchase. It is crucial, thus, for e-vendors to profit from the communication supplied by OCRs and improve it in a manner that guarantees the previously mentioned characteristics are involved.

\section{Limitations and Recommendations for Future Researches}

Primarily, this study tried to depict an understanding of the effects of OCRs features on customer trust and purchase intention. Despite the fact that the procured results appear to be motivating a few limitations should be considered in this study. Firstly, the data that was used for analysis has been obtained based on the accessibility and subjective opinion of the researcher. Secondly, despite the fact that respondents prior to filling in surveys were given detailed information about its purpose and objective, surveys carried self-reported nature. Thirdly, only five OCRs features (based on collected literature within study scope) have been analyzed in the current study. There might other critical OCRs features that impact the trust and the purchase intention of customers living in turkey in a serious way. Especially knowing that shopping behavior and culture may differ amongst countries; thus, it is advised to examine the framework in other countries. Fourthly, the acquired results probably won't be accessible and available after a certain period, and the model might require specific updates and adjustments later on. Finally, the limited time was another constraint that the researcher faced during the research period. It will be interesting to direct future researches to have mixed outcomes that will include both customer, e-vendor and business perspectives. In this way, we will be able to see the picture as a whole and fill in existing gaps in a more efficient manner. Also, to perform the same study of how the influence of online consumer reviews impacts consumers' purchase intention within different countries. Moreover, it will be interesting to perform a study on the online consumer reviews with a different method approach or different sector. It is possible to look into more detail on how the impact of negative and positive reviews influence consumers' purchase intentions. Concerning companies, it will be beneficial for them to give the opportunity to customers to write their reviews or feedbacks about certain products and services and take it into consideration. This will provide them a better understanding of what their customers prefer or dislike and help them focus on improving their lacks. The use of eWOM within customers is increasing whether to look for product information or to find one. Therefore, if companies don't allow them or don't offer them the possibility to share this information, other websites will take advantage of this opportunity. 


\section{References}

Agag, G., \& El-Masry, A. A. (2016). Understanding the determinants of hotel booking intentions and moderating role of habit. International Journal of Hospitality Management, 54, 52-67.

Akman, I., \& Mishra, A. (2015). Sector diversity in green information technology practices: technology acceptance model perspective. Computers in human behavior, 49, 477-486.

Alalwan, A. A., Baabdullah, A. M., Rana, N. P., Tamilmani, K., \& Dwivedi, Y. K. (2018). Examining adoption of mobile internet in Saudi Arabia: Extending TAM with perceived enjoyment, innovativeness and trust. Technology in Society, 55, 100-110.

Awad, N. F., \& Ragowsky, A. (2008). Establishing trust in electronic commerce through online word of mouth: An examination across genders. Journal of Management Information Systems, 24(4), 101-121.

Baek, H., Ahn, J., \& Choi, Y. (2012). Helpfulness of online consumer reviews: Readers' objectives and review cues. International Journal of Electronic Commerce, 17(2), 99-126.

Bertrandias, L., \& Goldsmith, R. E. (2006). Some psychological motivations for fashion opinion leadership and fashion opinion seeking. Journal of fashion marketing and management: an international journal, 10(1), 25-40.

Bolton, R. N., \& Lemon, K. N. (1999). A dynamic model of customers' usage of services: Usage as an antecedent and consequence of satisfaction. Journal of marketing research, 36(2), 171-186.

Byrne, B. M. (2010). Multivariate applications series. Structural equation modeling with AMOS: Basic concepts, applications, and programming (2nd ed.). New York, NY, US: Routledge/Taylor \& Francis Group.

Cheema, A., \& Papatla, P. (2010). Relative importance of online versus offline information for Internet purchases: Product category and Internet experience effects. Journal of Business Research, 63(9-10), 979-985.

Chen, P. Y., Wu, S. Y., \& Yoon, J. (2004). The impact of online recommendations and consumer feedback on sales. ICIS 2004 Proceedings, 58.

Chen, Y. H., \& Barnes, S. (2007). Initial trust and online buyer behaviour. Industrial management \& data systems, 107(1), 21-36.

Cheskin Research and Studio Archetype/Sapient, 1999. Ecommerce trust study, http://www.sapient.com/cheskin/, accessed 5/9/2000.

Cheung, C. M., \& Lee, M. K. (2012). What drives consumers to spread electronic word of mouth in online consumer-opinion platforms. Decision support systems, 53(1), 218-225.

Cheung, C. M., Lee, M. K., \& Rabjohn, N. (2008). The impact of electronic word-of-mouth: The adoption of online opinions in online customer communities. Internet Research: Electronic Networking Applications and Policy, 18(3), 229-247.

Chevalier, J. A., \& Mayzlin, D. (2006). The effect of word of mouth on sales: Online book reviews. Journal of marketing research, 43(3), 345-354.

Cho, D. Y., Kwon, H. J., \& Lee, H. Y. (2007, January). Analysis of trust in internet and mobile commerce adoption. In 2007 40th Annual Hawaii International Conference on System Sciences (HICSS'07) (pp. 50-50). IEEE.

Chung, J. E., Park, N., Wang, H., Fulk, J., \& McLaughlin, M. (2010). Age differences in perceptions of online community participation among non-users: An extension of the Technology Acceptance Model. Computers in Human Behavior, 26(6), 1674-1684.

Cronin Jr, J. J., Brady, M. K., \& Hult, G. T. M. (2000). Assessing the effects of quality, value, and customer satisfaction on consumer behavioral intentions in service environments. Journal of retailing, 76(2), 193-218. 
K. Dhahak - F. Huseynov 12/2 (2020) 990-1005

Cui, H., Kong, Y., \& Zhang, H. (2012). Oxidative stress, mitochondrial dysfunction, and aging. Journal of signal transduction, 2012.

Davis, F. D. (1989). Perceived usefulness, perceived ease of use, and user acceptance of information technology. MIS quarterly, 319-340.

Davis, F. D., Bagozzi, R. P., \& Warshaw, P. R. (1989). User acceptance of computer technology: a comparison of two theoretical models. Management science, 35(8), 982-1003.

Davis, F. D., Bagozzi, R. P., \& Warshaw, P. R. (1992). Extrinsic and intrinsic motivation to use computers in the workplace 1. Journal of applied social psychology, 22(14), 1111-1132.

Elwalda, A., \& Lu, K. (2014). The influence of online customer reviews on purchase intention: the role of nonnumerical factors. In Proceedings of the LCBR European Marketing Conference 2014.

Elwalda, A., \& Lu, K. (2016). The impact of online customer reviews (OCRs) on customers' purchase decisions: An exploration of the main dimensions of OCRs. Journal of customer Behaviour, 15(2), 123-152.

Elwalda, A., Lü, K., \& Ali, M. (2016). Perceived derived attributes of online customer reviews. Computers in Human Behavior, 56, 306-319.

eMarketer.com., Online review sway shoppers, Retrieved from http://www.emarketer.com/Article.aspx?R=10064042008 Last Accessed. 05.12.19.

Fu, X., Bin, Z., Xie, Q., Liuli, X., \& Yu, C. (2011). Impact of quantity and timeliness of EWOM information on consumer's online purchase intention under C2C environment. Asian Journal of Business Research, $1(2), 37-52$.

Gefen, D., Karahanna, E., \& Straub, D. W. (2003). Inexperience and experience with online stores: The importance of TAM and trust. IEEE Transactions on engineering management, 50(3), 307-321.

Gefen, D., Karahanna, E., \& Straub, D. W. (2003). Trust and TAM in online shopping: An integrated model. MIS quarterly, 27(1), 51-90.

Ha, S., \& Stoel, L. (2009). Consumer e-shopping acceptance: Antecedents in a technology acceptance model. Journal of business research, 62(5), 565-571.

Hampton-Sosa, W., \& Koufaris, M. (2005). The effect of web site perceptions on initial trust in the owner company. International Journal of Electronic Commerce, 10(1), 55-81.

Harrington, D. (2009). Confirmatory factor analysis. Oxford university press.

Hassanein, K., \& Head, M. (2005). The impact of infusing social presence in the web interface: An investigation across product types. International Journal of Electronic Commerce, 10(2), 31-55.

Hennig-Thurau, T., Gwinner, K. P., Walsh, G., \& Gremler, D. D. (2004). Electronic word-of-mouth via consumer-opinion platforms: what motivates consumers to articulate themselves on the internet? Journal of interactive marketing, 18(1), 38-52.

Hoffman, D. L., Novak, T. P., \& Peralta, M. (1999). Building consumer trust online. Communications of the ACM, 42(4), 80-85.

Horst, M., Kuttschreuter, M., \& Gutteling, J. M. (2007). Perceived usefulness, personal experiences, risk perception and trust as determinants of adoption of e-government services in The Netherlands. Computers in human behavior, 23(4), 1838-1852.

Hsu, C. L., \& Lin, J. C. C. (2008). Acceptance of blog usage: The roles of technology acceptance, social influence and knowledge sharing motivation. Information \& management, 45(1), 65-74.

Hsu, C. L., Lin, J. C. C., \& Chiang, H. S. (2013). The effects of blogger recommendations on customers' online shopping intentions. Internet Research. 23(1), 69-88.

Hu, N., Liu, L., Bose, I., \& Shen, J. (2010). Does sampling influence customers in online retailing of digital music?. Information Systems and e-Business Management, 8(4), 357-377. 
K. Dhahak - F. Huseynov 12/2 (2020) 990-1005

Hui, M. K., \& Bateson, J. E. (1991). Perceived control and the effects of crowding and consumer choice on the service experience. Journal of consumer research, 18(2), 174-184.

Huseynov, F., Amazhanova, K. (2018). The Impact of Electronic Customer Relationship Management on Customer Satisfaction in Turkey. Yönetim, Ekonomi ve Pazarlama Araştırmaları Dergisi 2(4), pp. 1226.

Ivan, K. L., Connie, C. H., \& Walter, W. C. (2010, October). Preliminary study of green manufacturing technology acceptance in China. In 2010 8th International Conference on Supply Chain Management and Information (pp. 1-7). IEEE.

Jarvenpaa, S. L., \& Todd, P. A. (1996). Consumer reactions to electronic shopping on the World Wide Web. International Journal of electronic commerce, 1(2), 59-88.

Jarvenpaa, S. L., Tractinsky, N., \& Saarinen, L. (1999). Consumer trust in an Internet store: A cross-cultural validation. Journal of Computer-Mediated Communication, 5(2), JCMC526.

Katie, H. (2015, May, 26). From Reviews to Results: The Impact of Business Software Reviews Retrieved from https://www.capterra.com/b2b-software-reviews-infographic

Kim, S. S., Malhotra, N. K., \& Narasimhan, S. (2005). Research note-two competing perspectives on automatic use: A theoretical and empirical comparison. Information systems research, 16(4), 418-432.

Kim, S., \& Park, H. (2013). Effects of various characteristics of social commerce (s-commerce) on consumers' trust and trust performance. International Journal of Information Management, 33(2), 318-332.

Koufaris, M. (2002). Applying the technology acceptance model and flow theory to online consumer behavior. Information systems research, 13(2), 205-223.

Koufaris, M., \& Hampton-Sosa, W. (2004). The development of initial trust in an online company by new customers. Information \& management, 41(3), 377-397.

Kumar, N., \& Benbasat, I. (2006). Research note: the influence of recommendations and consumer reviews on evaluations of websites. Information Systems Research, 17(4), 425-439.

Lan, H., \& Yizeng, C. (2014). Moderating effect of website types in the relationship between trust and consumers' intention to use online shopping. American Journal of Business and Management, 3(1), 60-69.

Lee, M. K., \& Turban, E. (2001). A trust model for consumer internet shopping. International Journal of electronic commerce, 6(1), 75-91.

Lee, M. K., Cheung, C. M., \& Chen, Z. (2005). Acceptance of Internet-based learning medium: the role of extrinsic and intrinsic motivation. Information \& management, 42(8), 1095-1104.

Legris, P., Ingham, J., \& Collerette, P. (2003). Why do people use information technology? A critical review of the technology acceptance model. Information \& management, 40(3), 191-204.

Li, S. J., \& Zhu, T. H. (2013). Biochemical response and induced resistance against anthracnose (C olletotrichum camelliae) of camellia (C amellia pitardii) by chitosan oligosaccharide application. Forest Pathology, 43(1), 67-76.

Li, X., Hitt, L. M., \& Zhang, Z. J. (2011). Product reviews and competition in markets for repeat purchase products. Journal of Management Information Systems, 27(4), 9-42.

Lim, K. S., Lim, J. S., \& Heinrichs, J. H. (2008). Testing an integrated model of e-shopping web site usage. Journal of Internet Commerce, 7(3), 291-312.

Limayem, M., Khalifa, M., \& Frini, A. (2000). What makes consumers buy from Internet? A longitudinal study of online shopping. IEEE Transactions on systems, man, and Cybernetics-Part A: Systems and Humans, 30(4), 421-432. 
K. Dhahak - F. Huseynov 12/2 (2020) 990-1005

Ling, K. C., Daud, D. B., Piew, T. H., Keoy, K. H., \& Hassan, P. (2011). Perceived risk, perceived technology, online trust for the online purchase intention in Malaysia. International Journal of Business and Management, 6(6), 167.

Lou, H., Chau, P. Y., \& Li, D. (2005). Understanding individual adoption of instant messaging: An empirical investigation. Journal of the Association for information systems, 6(4), 5.

Mayer, R. C., Davis, J. H., \& Schoorman, F. D. (1995). An integrative model of organizational trust. Academy of management review, 20(3), 709-734.

McKnight, D. H., Choudhury, V., \& Kacmar, C. (2002). The impact of initial consumer trust on intentions to transact with a web site: a trust building model. The journal of strategic information systems, 11(3-4), 297-323.

Moon, J. W., \& Kim, Y. G. (2001). Extending the TAM for a World-Wide-Web context. Information \& management, 38(4), 217-230.

Mudambi, S. M., \& Schuff, D. (2010). Research note: What makes a helpful online review? A study of customer reviews on Amazon. com. MIS quarterly, 34(1),185-200.

Okazaki, S. (2009). Social influence model and electronic word of mouth: PC versus mobile internet. International Journal of Advertising, 28(3), 439-472.

Pallant, J. (2013). SPSS survival manual. McGraw-Hill Education (UK).

Palvia, P. (2009). The role of trust in e-commerce relational exchange: A unified model. Information \& management, 46(4), 213-220.

Pan, Y., \& Zhang, J. Q. (2011). Born unequal: a study of the helpfulness of user-generated product reviews. Journal of retailing, 87(4), 598-612.

Park, C. H., \& Kim, Y. G. (2008). Identifying key factors affecting consumer purchase behavior in an online shopping context. International journal of retail \& distribution management 31(1), 16-29.

Park, D. H., \& Lee, J. (2008). eWOM overload and its effect on consumer behavioral intention depending on consumer involvement. Electronic Commerce Research and Applications, 7(4), 386-398.

Park, D. H., Lee, J., \& Han, I. (2007). The effect of on-line consumer reviews on consumer purchasing intention: The moderating role of involvement. International journal of electronic commerce, 11(4), 125-148.

Pavlou, P. A. (2003). Consumer acceptance of electronic commerce: Integrating trust and risk with the technology acceptance model. International journal of electronic commerce, 7(3), 101-134.

Phelps, J. E., Lewis, R., Mobilio, L., Perry, D., \& Raman, N. (2004). Viral marketing or electronic word-of-mouth advertising: Examining consumer responses and motivations to pass along email. Journal of advertising research, 44(4), 333-348.

Rose, S., Clark, M., Samouel, P., \& Hair, N. (2012). Online customer experience in e-retailing: an empirical model of antecedents and outcomes. Journal of retailing, 88(2), 308-322.

Schindler, R. M., \& Bickart, B. (2005). Published word of mouth: Referable, consumer-generated information on the Internet. Online consumer psychology: Understanding and influencing consumer behavior in the virtual world, 32, 35-61.

Schindler, R. M., \& Bickart, B. (2012). Perceived helpfulness of online consumer reviews: The role of message content and style. Journal of Consumer Behaviour, 11(3), 234-243.

Schlosser, A. E., White, T. B., \& Lloyd, S. M. (2006). Converting web site visitors into buyers: how web site investment increases consumer trusting beliefs and online purchase intentions. Journal of marketing, 70(2), 133-148.

Sen, S. (2008). Determinants of consumer trust of virtual word-of-mouth: an observation study from a retail website. Journal of American Academy of Business, 14(1), 30-35. 
K. Dhahak - F. Huseynov 12/2 (2020) 990-1005

Sen, S., \& Lerman, D. (2007). Why are you telling me this? An examination into negative consumer reviews on the web. Journal of interactive marketing, 21(4), 76-94.

Senecal, S., \& Nantel, J. (2004). The influence of online product recommendations on consumers' online choices. Journal of retailing, 80(2), 159-169.

Shi, X., \& Liao, Z. (2017). Online consumer review and group-buying participation: The mediating effects of consumer beliefs. Telematics and Informatics, 34(5), 605-617.

Smith, S. M., \& Albaum, G. S. (2005). Fundamentals of marketing research. Sage.

Sweeney, J. C., \& Soutar, G. N. (2001). Consumer perceived value: The development of a multiple item scale. Journal of retailing, 77(2), 203-220.

Tabachnick, B. G., Fidell, L. S., \& Ullman, J. B. (2007). Using multivariate statistics (Vol. 5). Boston, MA: Pearson.

Van Dolen, W. M., Dabholkar, P. A., \& De Ruyter, K. (2007). Satisfaction with online commercial group chat: the influence of perceived technology attributes, chat group characteristics, and advisor communication style. Journal of retailing, 83(3), 339-358.

Venkatesh, V. (2000). Determinants of perceived ease of use: Integrating control, intrinsic motivation, and emotion into the technology acceptance model. Information systems research, 11(4), 342-365.

Willemsen, L. M., Neijens, P. C., \& Bronner, F. (2012). The ironic effect of source identification on the perceived credibility of online product reviewers. Journal of Computer-Mediated Communication, 18(1), 16-31.

Wolfinbarger, M., \& Gilly, M. C. (2001). Shopping online for freedom, control, and fun. California management review, 43(2), 34-55.

Yayll, A., \& Bayram, M. (2012). eWOM: The Effects of Online Consumer Reviews On Purchasing Decision.International Journal of Internet Marketing and Advertising, 7(1). 